http://dx.doi.org/10.4314/ejotmas.v7i1-2.5

\title{
DANCE AND CONTENT ISSUES: IMPLICATIONS FOR CONTEMPORARY INDIGENOUS DANCE IN NIGERIA
}

\author{
*Princewill C. ABAKPORO
}

\begin{abstract}
Many traditional dances have witnessed downturn in patronage to occasion academic debates geared towards reviving interest in indigenous performances and live theatres in Nigeria. It is within this context that this article closely look at content issues in Nigerian indigenous dance from a diachronic perspective and observed that the seeming dwindling patronage for certain Nigerian indigenous dances is as a result of the inability of indigenous dance creators and performers to package indigenous dance products to reflect popular tastes in contemporary times. Also, it is observed that content issues in art are indicators that human society is constantly in a state of flux and that as humanity responds to these changing realities; art must do the same to remain relevant to the society within a particular period. Drawing on this, the study concludes that Nigerian indigenous dance space could be enlivened when its contents are at par with dominant societal realities and respond to prevailing societal conditions within the time of its creation while retaining its structures and form as a cultural document for the people. It recommended that the approach, packaging, and performance of indigenous dances from formalist and philosophical aesthetic consciousness will aid in the malleability of traditional dance contents to satisfy changing societal and audience needs.
\end{abstract}

Keywords: Traditional dance, Indigenous dance art, Nigeria, Content issues, Patronage

\section{Introduction}

Indigenous dance is a major factor in cultural delineation whose nature and scope touch all spheres of existence by way of establishing links with the physical, environmental, and cosmic terrains, which are constantly changing. Since academic insights greeted dance art, the

*Princewill C. ABAKPORO is of the Department of Theatre and Media Studies Gregory 
overriding issue in the subject has been its content. Content issues play a key role in the decision to consume any product, including art. The content of the product must be able to address the consumer's needs in terms of aesthetics and functionality in order to compete favourably with other products of the same value. In other words, content has remained key to the patronage of art products within a period in society. Virtually every dimension taken in the study of indigenous dance art since the modern period points to the need to project, modify, explain, and give theatrical validations to its content. Beyond the parameters for decoding the content and semiotic elements in indigenous dances, this article looks at the dialectic nature of traditional dance contents within the three distinct periods (pre-colonial, colonial and modern) of Nigeria's development and its implications for the contemporary society. The researcher scopes content to encapsulate the philosophy, semiotics, and movement vocabularies of the indigenous dance form as they relate to the society. Examining content manifestations and issues in indigenous dance from a diachronic perspective helps the study to identify changes in the performance and patronage levels of Nigerian indigenous dance. It will also help establish the need for adopting philosophical aesthetic thoughts in approach and execution of indigenous dance in contemporary Nigeria while retaining its nomenclature as indigenous property. Indigenous as used in this research is scoped to include and refer to the traditional dance forms wherein both traditional and indigenous dance may be used interchangeably.

Indigenous dances are social art forms that help to navigate activities in society in the sense that they have contributed to communication, survival, and existence. In Africa, dance helps to delineate geographical enclaves and shape cultural ethos within the geographical space. In this regard, Akas claims that it is through the means of identification that dance in Africa were named, traced to a particular ethnicity and understood as the socio-cultural methodology around its existence (128). Although, Nigeria can boast of a robust dance tradition, the patronage and consumption of indigenous dance in contemporary Nigeria seem to have waned due to environmental changes and the consequent emerging realities.

\section{Content Dialectics in Indigenous Dance: Pre-Colonialism to Post-Colonialism}

The place of dance as a socio-cultural art in any period of Nigeria's development cannot be overemphasized. In pre-colonial Nigeria, almost all aspects of existence could be linked to dance which served as a symbolic medium to communicate and address communal issues 
relating to religion, survival and existence that are both social and cosmic. Yerima posits that:

\begin{abstract}
It is right to say that African pre-colonial dances can be seen as a sacred language of every individual community, a link to the gods who look after them for each god is adorned with his own myth, colour, powers, shrine, music, and dance. This was a means of communication in symbolic shapes, which retell and foretell man's needs from the gods. It led to the contortions of the human body into symbols and images, which evoke human emotions such as enjoyment, fun while documenting man's history. (4)
\end{abstract}

The foregoing speaks to the fact that dance is created to reflect the cosmic views of the community, as the dependence on deities and gods was the dominant socio-cultural reality during the period. Since the art mainly revolved around deities and gods, they are first functional before they are aesthetic in the sense that these dances must first fulfill one cosmic principle or they become aesthetic to the host community. Nwaru validates this position, thus; factors considered as aesthetic (costumes, makeup, sound, light, scenic designs, movements, etc.) were functional in the dances and were employed to aid the dance achieve its performance goals. Even in recreation, dances were functional at least, if for nothing else, the celebration of cultural virtues and values (40). Placed against this backdrop, the dancer becomes a medium; an embodiment of socio-cultural symbols projected back and forth the cosmic terrains of the host community to achieve results by way of placating the gods or compelling cosmic intervention on communal affairs. Elldsfeldt affirms that a dancer is a kind of magician who sets out to perform a number of different acts of magic. He may use his powers to overcome an enemy, encourage growth of crops, or mark the coming of age of a young man. He may dance to celebrate his national origins, perpetuate tales of ethnic heroes, entertain his fellow, or just to enjoy himself (ix).

Dances within this period were created to embody the "virtues, cores and norms of indigenous societies borne out of their cosmological and communal patronage" (Abakporo 255). The art of indigenous dancing for Nigerian communities was limitless in scope as it ran from birth through death, from one generation to another. It is this view that likely informed Suru to conclude that indigenous dances in Nigeria "are like clothes, worn to celebrate life in all its ramifications. From birth to death, and 'after,' dance and music serve as a navigator of 
man's way of life and the directional sign(s) towards a better, peaceful and purposeful human existence" (194). Similarly, on his examination of the nature of Nigerian dance, Gorer claims that "Africans danced for everything. They dance for joy, and they dance for grief; they dance for love and they dance for hate; they dance to bring prosperity and they dance to avert calamity; they dance for religion and they dance to pass time" (213). Through dance movements, the existence and way of life of a people are expressed. Furthermore, Charlmers observes that indigenous dances are expressionistic tools utilized to capture, express, embody and formulate any given representation of our transitional indigenous culture. They are used, in their unique forms, accompanied by semiotic songs and music, to entertain and educate the indigenes (1).

Social structure and traditional values of the people are dominant features of indigenous dancing. The elements of rhythm, songs, movement, costume, range of movements, tempo and floor patterns are symbolic of the nature of communal expressions and relationships within the social, religious and cultural contexts. Tierous-Doople states that indigenous dance in Africa is used as a functional tool for expression and has and is used for a variety of reasons. It is used for ritualistic purposes, aesthetic enjoyment, courtship, personal communication and cultural continuity cum sustainability (1). Corroboratively, Abakporo remarks that dance for us is like a mirror through which we cast a glance at our past (a retrospective medium) as well as a standard for evaluating the present and peeping/securing our future with a view to harness and project our cultural norms and ethos (101). The art enjoyed pride of place in pre-colonial Nigeria as its audience consumed the product chiefly as a matter of rite, in the bid to present themselves as bona fide members of the community, assure themselves of the favour of the gods, reiterate and project their communal values and ethos, and partake in the expected positive results of the performance.

The art of dance within the colonial era was such that reacted to new and radical realities forced on the rubrics of traditionalism. Dance responded to the presentation of colonial realities of civilization, which shook the cores of Nigeria's pre-colonial setup. Colonial radical imposition of 'alien' religion, media, education, and political system had adverse effects on indigenous cultural and cosmic status quo. The evangelization techniques of the colonial campaign resulted in the hampering of religious views as Yerima's research on the growth of Igbo dances revealed that "the colonial invasion combined with the early Christian missionaries and their condemnation of ritual as paganism and barbarism affected the growth of most Igbo indigenous dance performances including masking" (67). In a more direct sense, 
Osuagwu reveals that: it was the introduction of Christianity to Nigeria that made the desecration of traditional shrines, the vandalization of cultural objects, and the systematic burning of art works... cultural property became the target of religious zealots... the introduction of Islam also assaulted our traditional ethos and social values as it averse to representation art (575).

The contents of indigenous dance within the colonial period reflected a partial or total distortion of the pre-colonial ideals. Colonialism brought about new religious, economic, aesthetic, and political changes that competed and almost displaced the communal setup of the traditional societies. In the words of Ukaegbu, the changes brought about by colonialism and Christianity led to, among other things, the loss of or deliberate rejection of sections of performance narratives with obvious references to indigenous religious rituals. When the forms and practices of such performance re-emerged many of them became overtly codified and abstracted (36). The final blow that twisted the fortunes of indigenous dances was the fact that these revered deities that govern people's existence could not protect themselves from the new religious invasion of the colonial masters. This consequently, affected the belief and followership attached to them as Nwabueze corroborates that:

The oracles were destroyed and heavy casualties inflicted on the defenders of the oracles. The leaders were arrested and publicly executed... this kind of destruction not only inflicted heavy losses in terms of material and wealth ... but also made them lose confidence in their respected ancestral spirits. Until the advent of the British, the Igbos had believed in the invincibility of their ancestors and the utilitarian functions of the rituals... their ancestors they thought, were now incapable of protecting themselves against the aliens who inflicted heavy physical assaults on them and desecrated the land. Thus the belief of even the most dedicated natives began to decline. (81-82)

Following this, the new religion prevailed and became a framework according to Nwaru; "judging these traditional belief and cultural systems. Anything that do not conform to written pages of the Bible or to the ideals of the Whiteman was regarded as sinful and treasonable to the successful institution of Her Majesty's system of governance in existence at the time" (42). Having crushed the religious and mythic 
essence of indigenous dances and culture through Christianity and formal education, they introduced their own dance forms on our soil and projected these dances through the media. It is on this backdrop that contents in indigenous dances shifted from response expectation from cosmic forces to response from human audiences as Nwabueze claims that stripping the performances of the components abhorred by both church and state transformed the nature of the performances... The intention of the performances shifted from the expectation of results from supernatural forces to expectation of reaction from a human audience... collective responsibility gave rise to individual creativity... emphasis shifted from pacification and cleansing to entertainment pleasure, and talent, rather than traditional expertise, became the over-riding principle (85).

The above situation of result expectancy from human audiences gave aesthetics an independent place in the structural makeup of indigenous dances as reversal to the pre-colonial order of being first, functional before aesthetic. The issue led to the degeneration of even the most sacred dances in some communities to mere entertainment and pleasurable relaxation for host communities. Education and media as tools were helpful in the colonial campaign against traditionalism in Nigeria. They helped to psychologically invade and reshape the perception of some members of the community towards communal activities. Osuagwu adds that "as more people became exposed to western education and ideas, an inferiority complex towards traditional values was cultivated. They therefore, no longer saw anything good in their cultural identity but termed them as pagan, fetish, or even evil" (570). In fact, Achebe aptly describes the colonial period and its effects on indigenous culture when he states that:

The Whiteman is very clever; he came quietly and peaceably with his religion. We were amused at his foolishness and allowed him to stay. Now he has won our brothers and our clan can no longer act like one. He has put a knife on the things that held us together and we have fallen apart. (124)

Post-colonial Nigeria was supposedly a period of revival and reclamation of the perceived culturally, politically, economically and socially plundered Nigeria. However, the footprints of colonial masters still rubbed-off on independent Nigeria like fingerprints of the potter on the pot. Several colonial structures such as religion, economy, media, technology and education were retained, and rather than recover the plundered Nigeria, it became a continuation of the colonial status quo. Indigenous dance after colonialism in Nigeria saw a gleam 
of hope as Nigeria attempted to recover, reclaim and culturally restore the nation. FESTAC ' 77 marked a general turnaround for Nigerian theatre as it led to the establishments of national and state councils for arts and culture to uphold the performative, plastic, and visual culture of the people. This period, however, ushered in the battle for aesthetics in the performing arts leading to various approaches and emerging dance forms. The media within this period also provided alternative relaxation for the proliferation of certain 'alien' and indigenously created dance forms such as the Galala, Konto, Makossa, Hip-hop, Naija, to the more recent Shoki, and Kukere dance movements that are competing heavily and are perceived to have overpowered or even banished the indigenous dance forms in the area of aesthetics.

Beyond threatening the existence of indigenous dance forms in the country, these alien intrusions ushered in a seeming battle for aesthetics wherein art products and institutions started to rethink their objectives and rebrand their products to remain relevant and retain their audience among their competitors. Music and drama adopted these intrusions and made adjustments to stay relevant but traditional dances seem not to be finding their feet in contemporary spaces as these intrusions were instead perceived as threatening. Hence, today there is a seeming decline in patronage of indigenous dance products and several traditional dance forms are fast losing their followership because of their inability to meet contemporary tastes.

\section{Approach to Content Issues: Implications for the Future of Indigenous Dance}

Judging from the foregoing analysis of the place of indigenous dance from pre-colonial to contemporary times, audience perception, interest, and patronage in indigenous dance theatres are waning as a result of media, educational, religious, political and aesthetic changes. As well, the perceived inability or perhaps, reluctance of indigenous dance to reinvent itself in response to these changes has been largely responsible for this. Instead these factors are perceived as threats to the development of indigenous dance and seem to threaten its survival beyond this millennium. It may not be superfluous to re-echo Nwamuo's thought that:

If the theatre and the arts form part of the everyday life of the average Nigerian, then they need to be sustained at all costs. If the theatre and the arts in all its ramifications represent the wealth of thought and life of a peoples' culture which must be nurtured, 
documented, propagated and passed on from one generation to another, then it is absolutely necessary that their survival be supported at all costs. (8-9)

It would be an attempt in futility to keep performing indigenous dances according to pre-colonial dictates with a post-colonial mindset. The audience and society of the former period are different in all ramifications from today's audience. Art must reflect the times of its creation and existence if it must remain relevant. Agbasiere substantiates this when he argued that ... the artist is influenced by the culture and event of the period. This situation is usually determined by the cultural perception of the society under which the artist lives and operates. It is important to note that the art of a given society emanates from their tradition and culture which are in constant evolution (20). Indigenous dance creators and performers must rethink and align indigenous dance content with the prevailing societal realities and the contemporary nature of audience especially in a time like this when views on traditionalism and certain cultural practices are in contention. On the other hand, as proof of societal metamorphosis, certain indigenous dances have also lost the cultural platform on which their essence is hinged. For instance, the Ohafia war dance is still performed today even though there are no more wars being fought in the area. The dance carves its relevance in the traditional myth of gallantry in war in the Ohafia region but in recent times, societies are seeking peaceful coexistence and performing the dance will be a matter of recounting and documenting history.

Revamping indigenous dance patronage and securing the future of indigenous dance will become realistic when indigenous dance creators begin to adopt the survivalist approaches by being open to the realities of today's society and incorporating these realities into their creations and performances rather than view them as threats to the indigenous dance forms. As these changes occur, the audience' need for and from the arts also change. The audience being the better half of the theatre and whose feedbacks tell on the image of the theatre should inform the creation of dance products to a great extent. Art has become a product that must exist and serve its audience or risk becoming irrelevant in time. Nwamuo that asserts that "it, therefore, becomes necessary that their needs, desires, wants where possible, interests and comfort be seriously considered... The customers' interest must override every production element..." (15). This calls for breaking the rigid structures of the indigenous dance forms and offering them up for contemporary inputs and innovations in choreography and design, yet retaining their miens as traditional 
dance forms. Here, the researcher advocates philosophical aesthetic and formalist perspectives in conceiving, creating and packaging indigenous dances. Indigenous dances can be repackaged to fit into new and contemporary spaces such as the proscenium stage. Adaptations from the residual nature of these dances on to the stage can aid the revival of waning interests in indigenous dance theatres. Consequently, contemporary audiences can readily identify with the dance forms and patronage revived.

Adopting the right approach to teaching and learning of indigenous dances play a role in turning the fortunes of indigenous dance forms around in the country. This is probably the surest way to ensure that traditional dances survived the onslaught of globalization and westernization. Education of choreographers is crucial in contemporary times as it equips the choreographers with skills to identify societal changes and renegotiate their approaches to reflect these changes through their artistic creations. If we agree that education is the key to survival of distinct dance forms, it means that we must adopt the right approach to the teaching of dance in higher institutions of learning where experts are expected to call the shots. Specialists in dance should be made to handle dance courses with the right practical and theoretical approaches instead of having nonprofessionals whose teaching styles as described by Nwaru; ... begins by explaining and describing what they read in dance books as they may not have enough experience in what they were teaching. Such so-called dance lecturers normally end up in dividing the class into groups for practical presentations without aiding or teaching the students the practical aspects of the course (86). Round pegs must fit into round holes in the teaching of dance within higher institutions as it implies the survival of indigenous dance and performative cultures. Also, the educational sector should factor the teaching of indigenous dances into the curricula of primary and secondary schools. This is to ensure that beside its health, fitness, and educational benefits for the children, it younger generations are taught cultural appreciation, thereby aiding the survival and patronage of indigenous dance art forms in Nigeria.

The media holds great influence in today's world and no business or endeavour (including contemporary theatre practices) can grow without its support or reportage. The media could serve as a platform for the expansion of the indigenous dance space. Instead of perceiving the media as a threat to indigenous dance forms, we can adopt it to publicise indigenous dances for contemporary audiences to appreciate. The media provides a universal appeal for indigenous dance forms when explored. Therefore, all aspects of the media should be explored for awareness and appreciation of the indigenous dance 
forms. For instance, programes can run on television revealing indigenous dances of various communities, well choreographed dances can feature as integral part of the plot in Nollywood films to restore the aplomb of indigenous dances. Important, too, the various councils for art and culture in Nigeria can upload sketches of their dances on the internet to boost the marketability of their arts beyond their existent domains. If we are to make any meaningful headway in reviving patronage and appeal of indigenous dance forms in Nigeria, the media is a key factor.

\section{Conclusion}

Art must flow in tandem with societal dynamics to satisfactorily reflect and address the prevailing realities of the times. Indigenous dance in contemporary times should be viewed as a product which when repackaged, has the potential of yielding economic gains while remaining the cultural property and document of the indigenous communities in Nigeria. To stay relevant in generations to come, dance contents must follow societal trends, reflect the cultural and aesthetic dynamics and realities of the changing period while serving as a medium for the people to patronize and celebrate their cultural heritage as culture is always in a state of flux.

\section{Works Cited}

Abakporo, Princewill. C. "Surviving in Postmodernism: Strategies for the Nigerian Indigenous Choreographer." Ikoro: Journal of Contemporary African Studies 10.1\&2 (2018):255-266. Print.

Pentecostalism as a Major Bane to the Development of Indigenous Dance Art in Nigeria. Education and Science Journal of Policy Review and Curriculum Development 5.1 (2015): 99-108. Print.

and Ajamgbe, Cyril. O. "Adjusting to Change: Reclaiming the Indigenous Dance Space in Contemporary Nigeria." JOTAMS: A Journal of Theatre and Media Studies 2.2 (2017): 61-72. Print.

Achebe, Chinua. Things Fall Apart. London: Heinemann, 1958. Print. Agbasiere, Chijioke. "Igbo Traditional Performing Arts and Sustenance." ObafConfab Book of Proceedings. Ed. Sunday E. Ododo and Charles Bodunde. Abuja: National Commission for Museum and Monuments, 2010: 207-215. Print.

Akas, Nicholas C. "The Dancer's Body Motif and its Traditional Implications: A Study of Oguamalam Masquerade Dance." JOTAMS: A Journal of Theatre and Media Studies 2.2 (2017): 127-133. Print. 
Chalmers, Samartha. "African Dance: The Continuity of Change." Year Book of International Folk Music Council 5(1973): 165-174. Print.

Ellfeldt, Lois. Dance from Magic to Art. New York: W.M.C Brown Company Publishers, 1980. Print.

Gorer, Geoffrey. Africa Dances. New York: W.W. Norton \& Company Inc. 1962. Print.

Nwabueze, Emeka. Visions and Revisions: Selected Discourses on Literary Criticism (2nd Ed.) Enugu: Abic Books, 2011. Print.

Nwamuo, Chris. Theatre Marketing Process. Calabar: Optimist Press Nig., 2007. Print.

Nwaru, Chris. "The Diachronic Development of Traditional Dance in Nigeria." JOTAMS: A Journal of Theatre and Media Studies 2. 2 (2017): 38-49. Print.

Osuagwu, Victoria. N. "Cultural Heritage as a Framework for the Promotion of Peace." ObafConfab Book of Proceedings. Ed. Sunday E. Ododo and Charles Bodunde. Abuja: National Commission for Museum and Monuments, 2010: 569-581. Print.

Suru, Damisa C. "The Aesthetics of Life in the Dance and Music of Ebira Festival." ObafConfab Book of Proceedings. Ed. Sunday E. Ododo and Charles Bodunde. Abuja: National Commission for Museum and Monuments, 2010: 194-206. Print.

Treror, Duople, A. Essence of Semiotics. Legon: University Press, 2004. Print.

Ukaegbu, Victor. The Use of Masks in Igbo Theatre in Nigeria: The Aesthetic Flexibility of Performance Traditions. Lewiston: Edwin Mellen Press, 2007. Print.

Yerima, Ahmed. "Culture, Dance and Change in a Democratic Nigerian Society" Dance Journal of Nigeria 3(2016): 4-16. Print. 